\title{
Penggunaan Eucheuma SP dan Chitosan Sebagai BaHan EDIBLE FILM TERHADAP KUALITASNYA
}

\author{
Dwi Setijawati* \\ Program Studi Teknologi Hasil Perikanan, \\ Fakultas Perikanan dan Ilmu Kelautan Universitas Brawijaya Malang \\ Email: setijawatis@gmail.com/dwisetyawati@ub.ac.id
}

\begin{abstract}
Abstrak
Caragenan dan chitosan merupakan bahan yang dapat digunakan sebagai bahan edible film. Tujuan penelitian adalah mencari pengaruh penggunaan bahan campuran antara kappa caragenan, iota caragenan dan chitosan dalam perbandingan terhadap kualitas edible film. Metode penelitian adalah laboratorium eksperimental desain dengan perlakuan yaitu campuran bahan kappa caragenan, iota caragenan dan chitosan dalam berbagai perbandingan; Variabel terikat meliputi: transmisi uap air, elongasi, uji kuat tarik, ketebalan. Desain penelitian ANOVA dengan Rancangan Acak Lengkap yang diulang 3 kali..Analisa data menggunakan SPSS 17.Hasil penelitian menunjukkan bahwa kualitas edible film yang diamati melalui uji tensile strength,elongasi,ketebalan dan transmisi uap air sangat dipengaruhi oleh bahan edible film, terutama penggunaan kappa caragenan dalam campurannya. Edible film yang tidak menggunakan bahan kappa caragenan menunjukkan kualitas yang tidak dapat diuji lanjut karena retak dan sobek dilihat dari morfologi.Perlakuan terbaik didapatkan pada perlakuan kappa caragenan, iota caragenan dan chitosan dalam perbandingan 3:1:0 dengan nilai elongasi 13,55\%;transmisi uap air 2,38 $\mathrm{g} / \mathrm{m}^{2}$.jam. Perbandingan bahan 3:0:1 memberikan nilai tensile strength sebesar $36,83 \mathrm{~N} / \mathrm{mm}^{2}$, ketebalan terendah sebesar $47,67 \mu \mathrm{m}$ pada perlakuan dengan perbandingan bahan 1:1:1. Kualitas terbaik diamati berdasarkan penampakan yang bening, transparan, tipis dengan nilai tensile strength dan elongasi tertinggi.
\end{abstract}

Key words : Eucheuma cottonii,Eucheuma spinosum,kulit udang

\section{Pendahuluan}

Dua spesies penting dan potensial di Indonesia adalah Eucheuma cottonii dan Eucheuma spinosum. Kedua spesies tersebut adalah penghasil kappa caragenan dan iota caragenan dengan menggunakan metode ekstraksi yang berbahan alkali. Sedangkan udang merupakan komoditas unggulan lain dalam bidang perikanan dan kelautan di Indonesia. Kulit udang merupakan limbah yang dapat dimanfaatkan sebagai kitin dan chitosan. Pemanfaatan kappa caragenan dan iota caragenan yang berasal dari Eucheuma sp serta kulit udang sebagai kitin dan chitosan sebagai bahan edible film merupakan upaya dalam rangka peningkatan nilai guna dan nilai tambah. Edible film adalah lembaran tipis yang terbuat dari bahan yang dapat dikonsumsi, ataupun sebagai pelapis dengan berbagai fungsi kegunaan. Menurut [1] menyatakan bahwa edible film dapat

\footnotetext{
*Corresponding Author

Email: setijawatis@gmail.com/dwisetyawati@ub.ac.id
}

digunakan sebagai penghalang terhadap gas dan uap air, melindungi bahan makanan yang rentan terhadap oksidasi, dan meningkatkan sifat mekanis pada produk makanan.Kualitas edible film yang diamati melalui tensile strength, elongasi, ketebalan dan transmisi uap air dipengaruhi oleh bahan dan campuran. Bahan pembentuk film dikategorikan menjadi tiga yaitu polisakarida termasuk hidrokoloid, lipid dan komposit.

Multikomponen edible film yang terdiri dari campuran dapat dikembangkan umtuk memiliki sifat fungsional yang dapat mempengaruhi kualitasnya. Caragenan adalah polisakarida yang diekstraksi dari rumput laut merah dari family Rodhophyceae. Sumber rumput laut komersial adalah Eucheuma cottonii, Eucheuma spinosum, Gigartina spp dan Chondrus crispus. Caragenan adalah polisakarida anionik linier tersusun dari unit 
galaktopyranosyl yang dihubungkan dengan ikatan glikosidik pada $\beta-(1,4)$ dan $\alpha(1,3)$.Unit gula adalah sulfat yang terletak pada C-2,C-3 atau C-6 dari galaktosa atau $\mathrm{C}-2$ pada unit anhydrogalaktosa. Disamping itu terdapatnya gugus 3.6 anhidrogalaktosa serta ester sulfat merupakan penanda caragenan ${ }^{[2]}$.

Chitosan adalah polisakarida kationik linier dengan poly- $\beta-(1,4) .2$ amino-deoksiD-glukopiranosa ${ }^{[2] .}$ Chitosan dalam bentuk free amina bersifat tidak larut dalam air pada $\mathrm{pH}$ netral. Akan tetapi chitosan larut dalam asam asetat glasial dan larutan $\mathrm{HCl}$, akan tetapi tidak larut dalam asam sulfur pada suhu kamar [3][4]. Karakteristik film yang terbuat dari beberapa campuran gum dipengaruhi oleh pengembangan intermolekul dari ikatan hydrogen diantara jalinan polimer yang timbul akibat perbedaan struktur polimer. secara teori, polisakarida non ionik linier dengan berat molekul tinggi menghasilkan film yang kuat [5].

Permasalahan adalah apakah campuran caragenan dalam bentuk kappa dan iota serta chitosan memberikan pengaruh terhadap kualitas edible film. Tujuan penelitian mencari pengaruh penggunaan bahan caragenan dan chitosan sebagai campuran dalam berbagai perbandingan terhadap kualitas edible film

\section{Materi Dan Metode Penelitian \\ 2.1 Pembuatan kappa caragenan}

Pembuatan kappa caragenan yang terbuat dari bahan Eucheuma cottonii menggunakan metode PNG yaitu Philipine Natural Grade [7] yang telah dikembangkan dengan menggunakn formulasi dan bahan ekstraksi yang sudah dimodifikasi [2] yaitu, rumput laut spesies Eucheuma cottonii kering ditimbang lalu dibersihkan. Kemudian rumput laut direbus dalam larutan $\mathrm{KOH}$ dengan konsentras $\mathrm{i} 6 \%(\mathrm{w} / \mathrm{v})$ dengan suhu $70-74^{\circ} \mathrm{C}$ selama 2 jam. Diambil dan dicuci dengan air bersih sampai bau $\mathrm{KOH}$ hilang sebagai langkah penetralan. Setelah itu rumput laut hasil ekstraksi dipotong dengan ukuran 2-3 cm, dilanjutkan dengan langkah pengeringan, setelah itu dilakukan penggilingan untuk menjadi Semi Refine Caragenan atau SRC bubuk [6].

\subsection{Pembuatan iota caragenan}

Pembuatan kappa caragenan yang terbuat dari bahan Eucheuma spinosum menggunakan metode PNG yaitu Philipine Natural Grade [7] yang dikembangkan melalui langkah dengan menggunakan formulasi dan bahan ekstraksi yang sudah dimodifikasi yaitu, rumput laut spesies Eucheuma spinosum kering ditimbang lalu dibersihkan. Kemudian rumput laut direbus dalam larutan $\mathrm{Ca}(\mathrm{OH})_{2}$ dengan konsentrasi $6 \%(\mathrm{w} / \mathrm{v})$ dengan suhu $70-74^{\circ} \mathrm{C}$ selama 2 jam. Diambil dan dicuci dengan air bersih sampai bau $\mathrm{Ca}(\mathrm{OH})_{2}$ hilang sebagai langkah penetralan. Setelah itu rumput laut hasil ekstraksi dipotong dengan ukuran 2-3 $\mathrm{cm}$, dilanjutkan dengan langkah pengeringan, setelah itu dilakukan penggilingan untuk menjadi Semi Refine Caragenan atau SRC bubuk [6].

\subsection{Pembuatan chitosan}

Pembuatan chitin dan chitosan menggunakan metode yang dilakukan oleh [8].Pembuatan khitosan dilakukan melalui dua tahap yaitu proses isolasi khitin dan proses pembuatan khitosan. Tahap isolasi khitin terdapat dua tahapan yaitu tahap deproteinase dan tahap demineralisasi. Tahap demineralisasi dilakukan dengan cara cangkang udang yang telah dikeringkan, kemudian dimasukkan kedalam beaker glass, setelah itu ditambahkan dengan $\mathrm{NaOH} 3,5 \%$ dengan perbandingan 1:10 $(w / v)$. Campuran larutan ini direndam selama \pm 2 jam pada suhu $65^{\circ} \mathrm{C}$, campuran ini diaduk dengan menggunakan magnetic stirrer. Langkah selanjutnya adalah cangkang udang yang telah direndam dicuci dengan akuades sampai $\mathrm{pH}$ netral. Langkah selanjutnya adalah mengeringkan cangkang tersebut dalam oven dengan suhu $80^{\circ} \mathrm{C}$ sampai kering dengan standar kadar air $11 \%$.

Selanjutnya dilakukan tahap demineralisasi, pada tahap demineralisasi, crude khitin yang telah dihasilkan dari tahapan proses sebelumnya, kemudian 
dimasukkan kedalam beaker glass dan ditambahkan larutan $\mathrm{HCl} 1 \mathrm{~N}$ dengan perbandingan crude khitin dan larutan $\mathrm{HCl}$ $1 \mathrm{~N}(1: 20)(w / v)$. Kemudian larutan tersebut dipanaskan diatas hotplate dan diaduk selama 30 menit. Selanjutnya dilakukan pencucian sampai $\mathrm{pH}$ netral. Setelah netral barulah dikeringkan didalam oven pada suhu $80^{\circ} \mathrm{C}$.Dari seluruh tahapan proses yang telah dilakukan akan menghasilkan khitin.

Proses selanjutnya adalah proses transformasi dari khitin menjadi chitosan, melalui langkah penambahan $\mathrm{NaOH}$ dan pemanasan. Tahapan yang dilalui adalah sebagai berikut Khitin yang telah dihasilkan, kemudian dimasukkan kedalam beaker glass dan ditambahkan $\mathrm{NaOH} \mathrm{50 \%}$ dengan perbandingan khitin dan larutan $\mathrm{NaOH}$ 1:20 (w/v). Campuran tersebut dipanaskan dengan suhu $120^{\circ} \mathrm{C}$ selama 2 jam. Kemudian campuran tersebut disaring dan dicuci dengan akuades sampai $\mathrm{pH}$ netral. Selanjutnya dikeringkan dengan oven pada suhu $80 \mathrm{oC}$ sampai kering, sehingga didapatkan chitosan.

\subsection{Pembuatan edible film dari kappa, iota dan Chitosan [9]}

Pembuatan edible film dalam penelitian ini menggunakan metoda [3] yang telah dimodifikasi. Pembuatan bahan edible film dalam penelitian ini terdiri dari campuran kappa caragenan, iota caragenan dan Chitosan dalam berbagai perbandingan yang sesuai dengan perlakuan. Adapun langkah pembuatannya mengikuti tahapan sebagai berikut yaitu : tepung kappa caragenan, iota caragenan dan chitosan ditimbang sebanyak 2 gram dengan perbandingan sesuai dengan perlakuan, masukkan kedalam gelas kimia kemudian panaskan dengan $80 \mathrm{ml}$ aquades diatas hot plate stirrer pada suhu $60^{\circ} \mathrm{C}$, tambahkan dengan gliserol sebagai plasticizer I $\mathrm{ml}$, dan ditambahkan aquades sehingga volumenya $100 \mathrm{ml}$, lalu panaskan pada suhu $80^{\circ} \mathrm{C}$ hingga homogen. Larutan kemudian dituang dalam nampan plastik lalu dikeringan dengan oven pada suhu $50^{\circ} \mathrm{C}$ selama $24 \mathrm{jam}$.

Peralatan yang digunakan dalam analisis fisika edible film yaitu Imada Force
Measurement tipe ZP-200N, hand micrometer, timbangan digital, oven, thermometer, inkubator, dan desikator. Alat yang digunakan dalam analisis kimia edible film yaitu uji kadar air menggunakan oven, desikator, botol timbang, penjepit dan mortar.

\subsection{Metode Penelitian}

Metode yang digunakan dalam penelitian ini adalah metode laboratorium eksperimen desain. Variabel bebas yang digunakan adalah Kappa caragenan, iota caragenan caragenan dan chitosan dalam berbagai perbandingan yaitu $\mathrm{A} 1(0: 1: 3)$; A2(0:2:2); A3(0:3:1); A4(1:0:3); A5(2:0:2); A6(3:0:1); A7(3:1:0); A8(2:2:0); A9(1:3:0); A10(1:1:1).

\subsection{Uji Tensile Strength [10]}

Analisis tensile strength dan elongasi dilakukan dengan menggunakan alat Imada Force Measurement tipe ZP-200N. Dengan mengikuti prosedur kerja alat maka akan mendapatkan data untuk tensile strength dan elongasi edible film. Dari alat tersebut akan didapatkan data untuk gaya (force) yang diperlukan untuk memutuskan edible film dan peranjangan edible film sampai edible film tersebut putus. Berikut ini adalah rumus untuk menghitung tensile strength dan elongasi edible film:

$$
\text { Tensile strength }(\mathrm{N} / \mathrm{cm} 2)=\frac{\text { Gaya }}{\text { Satuan Luas }(\mathrm{cm} 2)}
$$

2.7 Pengukuran Ketebalan (Santacruz et al, 2015, 2007) [9]

Pengukuran ketebalan edible film diukur dengan menggunakan hand micrometer dengan ketelitian $0,01 \mathrm{~mm}$ pada beberapa titik atau 3 titik berbeda, kemudian hasil pengukuran dirata-rata. Ketebalan film dinyatakan dalam satuan $\mathrm{mm}$ dan micrometer yang digunakan mempunyai ketelitian $\mu \mathrm{m}$. Ketebalan dapat dihitung dengan rumus :

$$
\text { Ketebalan }=\frac{\text { tebal atas }+ \text { tebal tengah }+ \text { tebal bawah }}{3}
$$

\subsection{Laju Transmisi Uap Air [10]}

Edible film yang akan diuji dipotong. Kemudian wadah diisi $15 \mathrm{~mL}$ aquadest dan 
ditempatkan di wadah 2 yang berisi silica gel. Sebelum itu, silica gel dikeringkan pada suhu $180^{\circ} \mathrm{C}$ selama 3 jam. Lalu wadah 2 disimpan pada suhu $25^{\circ} \mathrm{C}$. Pengukuran dilakukan setelah penyimpanan pada jam ke 24. Tranmisi uap air dihitung dengan rumus:

$\mathrm{WVP}=\frac{\Delta W}{t \times A}$

Dimana,

$\mathrm{W}=$ Perubahan edible film setelah 24 jam

$\mathrm{T}=$ Waktu $(24 \mathrm{jam})$

$\mathrm{A}=$ Luas permukaan film $\left(\mathrm{m}^{2}\right)$

\subsection{Elongasi [10]}

Persen elongasi dihitung dengan membandingkan panjang edible film saat putus dan panjang edible film sebelum ditarik oleh alat. Perhitungan persen pemanjangan tersebut dapat ditulis sebagai berikut :

$\%$ Elongasi=

$\frac{\text { Panjang akhir saat putus }(\mathrm{cm}) \text { - panjang awal }(\mathrm{cm})}{\text { panjang awal }(\mathrm{cm})} \times 100 \%$

\section{Hasil Dan Pembahasan \\ 3.1 Identifikasi Bahan Baku}

Identifikasi bahan edible film dengan mengamati gugus fungsi menggunakan FTIR. Hasil pengujian gugus fungsi menggunakan FTIR pada kappa caragenan, iota caragenan dan chitosan dapat dilihat secara berturut-turut pada Gambar 1,2 dan 3.

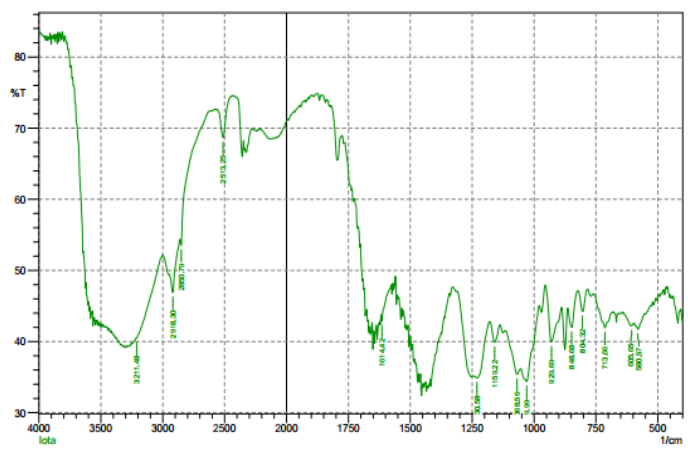

Gambar 1. Spektra Hasil FTIR Iota Caragenan dari bahan Eucheuma spinosum

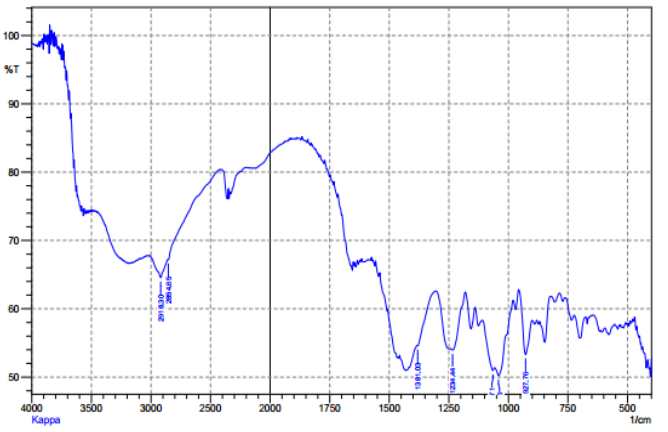

Gambar 2. Spektra hasil FTIR kappa caragenan dari bahan Eucheuma cottonii

Hasil penelitian yang diamati melalui Gambar 1 dan Gambar 2 dan tersaji pada Tabel 1 menunjukkan intensitas serapan yang ditunjukkan oleh ester sulfat, ikatan glikosidik dan galaktosa sangat kuat yang diamati berdasarkan bilangan gelombang.

Caragenan ditandai dengan gugus fungsi ester sulfat terdapat pada bilangan gelombang $\quad 1210-1260 \mathrm{~cm}^{-1}$, ikatan glikosidik pada 1010-1080 $\mathrm{cm}^{-1}$, AnhidroGalaktosa (AG) pada 928-933 $\mathrm{cm}^{-1}$, galaktosa sulfat pada $840-850 \mathrm{~cm}^{-1}$, dan galaktosa 2 sulfat pada $800-805 \mathrm{~cm}^{-1}$.

Intensitas serapan yang ditunjukkan oleh ester sulfat, ikatan glikosidik dan galaktosa sangat kuat. Eucheuma cottonii mengandung kappa caragenan yang tersusun dari (1,3)-D-galaktosa-4-sulfat dan (1,4)-3,6-Anhidro-D-Galaktosa. Sedangkan Eucheuma spinosum mengandung iota caragenan yang tersusun dari D-galaktosa4-sulfat dan 3,6-anhidro-D-galaktosa-2sulfat. Kappa caragenan dan iota caragenan sebagai bahan penelitian dibandingkan dengan standar dapat dilihat pada Tabel 1. 
Tabel 1.

Bilangan gelombang gugus fungsional kappa dan iota caragenan dibandingkan standar pada spektroskopi FTIR 8108 Shimadzu

\begin{tabular}{|c|c|c|c|c|}
\hline & $\begin{array}{c}\text { Kappa* } \\
\text { (standar) }\end{array}$ & $\begin{array}{c}\text { Iota* }^{*} \\
\text { (standar) }\end{array}$ & $\begin{array}{c}\text { Kappa } \\
(* *)\end{array}$ & Iota $(* *)$ \\
\hline $\begin{array}{l}\text { Ester } \\
\text { sulfat }\end{array}$ & 1261,8 & 1260 & 1258 & $\begin{array}{l}1241,11 \\
- \\
1262,32\end{array}$ \\
\hline $\begin{array}{l}\text { Ikatan } \\
\text { glikosidik }\end{array}$ & 1068,7 & 1072,6 & 1070 & $\begin{array}{l}1010- \\
1080\end{array}$ \\
\hline $\begin{array}{l}3,6 \\
\text { anhidro D- } \\
\text { galaktan }\end{array}$ & 929,8 & 931,7 & 937,7 & 930,59 \\
\hline $\begin{array}{l}\text { D- } \\
\text { galaktan-4 } \\
\text { SO4 } \\
\text { D- }\end{array}$ & 844,9 & 848,8 & 847,7 & 930,59 \\
\hline $\begin{array}{l}\text { galaktan-2 } \\
\text { SO4 }\end{array}$ & - & - & - & - \\
\hline D-gal-6S & - & - & - & - \\
\hline $\begin{array}{l}3,6- \\
\text { anhydro } \\
\text { galaktan- } \\
\text { 2SO4 }\end{array}$ & 802,5 & 804,4 & - & 804,26 \\
\hline
\end{tabular}

Keterangan:

(*) (Ramaniar, 1997) ${ }^{[11]}$

(**) hasil penelitian

Analisa gugus fungsi menggunakan FTIR dapat membedakan tipe caragenan yang dihasilkan. Hasil pengamatan gugus fungsi hasil penelitian yang dibandingkan dengan standar produk Sigma menyatakan bahwa bahan caragenan spesies Eucheuma cottonii dan Eucheuma spinosum yang digunakan sebagai bahan penelitian adalah caragenan tipe kappa dan caragenan tipe iota. Sehingga berdasarkan analisa gugus fungsi tersebut maka spesies Eucheumacottonii dan Eucheuma spinosum yang digunakan sebagai bahan penelitian adalah caragenan tipe kappa dan caragenan tipe iota. Sehingga berdasarkan analisa gugus fungsi tersebut maka spesies Eucheuma cottonii dan Eucheuma spinosum mempunyai ciri dengan keberadaan gugus Anhidro Galaktan (AG) sebagai pembentuk gel serta gugus ester sulfat yang mempengaruhi sifat gel. Sifat gel dapat mempengaruhi kualitas edible film.

Gambar 3. menunjukkan bahwa hasil spectra infra merah dengan Karakterisasi chitosan dilakukan menggunakan FTIR untuk diketahui gugus fungsinya .Hasil dari FTIRchitosan dapat dilihat pada Tabel 2.

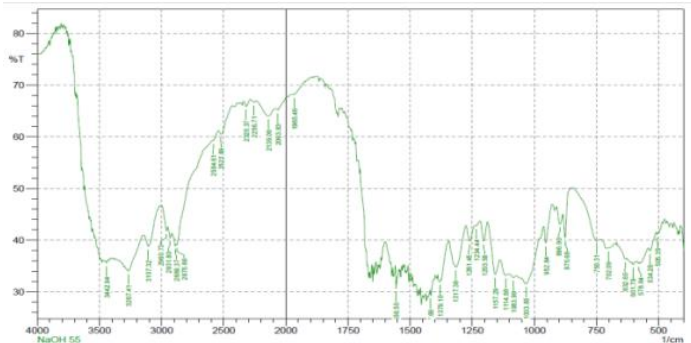

Gambar 3. Hasil spektra chitosan menggunakan FTIR

Tabel 2.

Gugus Fungsi Spektrum Infra Merah pada Chitosan

\begin{tabular}{cc}
\hline $\begin{array}{c}\text { Panjang } \\
\text { Gelombang }\left(\mathrm{cm}^{-1}\right)\end{array}$ & Gugus Fungsi \\
\hline $675-995$ & $\mathrm{C}-\mathrm{H}$ alkena \\
$690-900$ & $\mathrm{C}-\mathrm{H}$ cincin aromatik \\
$1050-1300$ & $\mathrm{C}-\mathrm{O}$ \\
$1180-1360$ & $\mathrm{C}-\mathrm{N}$ amina/amida \\
$1300-1370$ & $\mathrm{NO}_{2}$ \\
$1500-1570$ & $\mathrm{NO}_{2}$ \\
\hline
\end{tabular}

Berdasarkan hasil karakterisasi dengan FTIR chitosan pada gambar 3, muncul puncak pada serapan1315,45 $\mathrm{cm}^{-1}$ yang menunjukkan adanya gugus $\mathrm{C}-\mathrm{N}$ amina/amida, muncul puncak pada serapan $1379,1 \mathrm{~cm}^{-1}$ yang menunjukkan adanya gugus $\mathrm{C}-\mathrm{H}$ alkana tetapi dengan intensitas yang lemah, ini menunjukkan telah 1379,1 $\mathrm{cm}^{-1}$ yang menunjukkan adanya gugus $\mathrm{C}-\mathrm{H}$ alkana tetapi dengan intensitas yang lemah, ini menunjukkan telah terjadinya proses deasetilasi yang menyebabkan hilangnya sebagian besar gugus metil, $-\mathrm{CH}_{3}$, serta muncul puncak pada serapan 3232,7 dan $3263,56 \mathrm{~cm}^{-1}$ yang menunjukkan adanya gugus $\mathrm{O}-\mathrm{H}$ alcohol ikatan hydrogen. Pita serapan nengkokan $-\mathrm{CH}_{3}$ pada bilangan gelombang 1380,9 $\mathrm{cm}^{-1}$ masih muncul tetapi dengan intensitas yang lebih lemah, hal ini menunjukkan telah terjadinya proses deasetilasi yang menyebabkan hilangnya sebagian besar gugus metil, $-\mathrm{CH}_{3}$.

Gugus fungsi pada spektrum FTIR yang dilakukan pada chitosan sebagai bahan penelitian yang dibandingkan dengan penelitian yang dilakukan oleh [12] dapat dilihat pada Tabel 3. 
Tabel 3.

Gugus Fungsi Spektrum Infra Merah pada Chitosan

\begin{tabular}{ccc}
\hline Gugus Fungsi & $\begin{array}{c}\text { Panjang } \\
\text { Gelombang } \\
\left(\mathrm{cm}^{-1}\right)^{*}\end{array}$ & $\begin{array}{c}\text { Panjang } \\
\text { Gelombang } \\
\left(\mathrm{cm}^{-1}\right)^{* * * *}\end{array}$ \\
\hline $\mathrm{C}-\mathrm{O}$ & $1050-1300$ & 1157,2 \\
$\mathrm{C}-\mathrm{N}$ & $1180-1360$ & 1326,9 \\
amina/amida & & \\
\hline
\end{tabular}

Keterangan :

*) : Chitosan hasil penelitian

**) : Kurniasih dan Kartika

\subsection{Pengaruh perlakuan terhadap kualitas edible film}

Pembuatan edible film berbahan campuran kappa caragenan dan iota caragenan serta kitosan dilakukan dengan 10 perlakuan konsentrasi, yaitu $\mathrm{A}_{1}(0: 1: 3)$, $\mathrm{A}_{2}(0: 2: 2), \mathrm{A}_{3}(0: 3: 1), \mathrm{A}_{4}(1: 0: 3), \mathrm{A}_{5}(2: 0: 2)$, $\mathrm{A}_{6}(0: 0: 1), \quad \mathrm{A}_{7}(3: 1: 0), \quad \mathrm{A}_{8}(2: 2: 0), \quad$ dan $\mathrm{A}_{9}(1: 3: 0) ; \mathrm{A}_{10} \quad(1: 1: 1) \quad$ dengan 3 kali ulangan. Akan tetapi hasil edible film pada perlakuan $\mathrm{A}_{1}, \mathrm{~A}_{2}, \mathrm{~A}_{3}$ menghasilkan edible film dengan karakteristik yang buruk, sehingga tidak dapat di uji karakteristik fisik. Pada perlakuan $\mathrm{A}_{4}, \mathrm{~A}_{5}, \mathrm{~A}_{6}, \mathrm{~A}_{7}, \mathrm{~A}_{8}, \mathrm{~A}_{9}$ dan $\mathrm{A}_{10}$ dilakukan uji karakteristik edible film. Hasil setiap uji karakteristik edible film dapat dilihat pada Tabel 4.

Tabel 4.

Hasil analisa pengaruh perlakuan terhadap kualitas Edible Film

\begin{tabular}{ccccc}
\hline $\begin{array}{l}\text { Perlakuan } \\
\text { kappa:iota } \\
\text { :chitosan }\end{array}$ & $\begin{array}{l}\text { Tensile } \\
\text { Strength } \\
(\mathrm{N} / \mathrm{mm} 2)\end{array}$ & $\begin{array}{l}\text { Elongasi } \\
(\%)\end{array}$ & $\begin{array}{l}\text { Transmisi } \\
\text { Uap Air } \\
(\mathrm{g} / \mathrm{m} 2 . j \mathrm{jam})\end{array}$ & $\begin{array}{l}\text { Ketebalan } \\
(\mu \mathrm{m})\end{array}$ \\
\hline $\mathrm{A}_{4}$ & $34,82^{\mathrm{f}}$ & $8,66^{\mathrm{e}}$ & $32,25^{\mathrm{d}}$ & $88,79^{\mathrm{c}}$ \\
$\mathrm{A}_{5}$ & $22,13^{\mathrm{d}}$ & $5,56^{\mathrm{b}}$ & $32,26^{\mathrm{d}}$ & $56,73^{\mathrm{b}}$ \\
$\mathrm{A}_{6}$ & $36,83^{\mathrm{g}}$ & $8,28^{\mathrm{d}}$ & $101,09^{\mathrm{e}}$ & $100,09^{\mathrm{d}}$ \\
$\mathrm{A}_{7}$ & $22,13^{\mathrm{d}}$ & $13,55^{\mathrm{f}}$ & $2,38^{\mathrm{a}}$ & $101,17^{\mathrm{de}}$ \\
$\mathrm{A}_{8}$ & $11,14^{\mathrm{c}}$ & $7,69^{\mathrm{c}}$ & $5,72^{\mathrm{c}}$ & $111,31^{\mathrm{de}}$ \\
$\mathrm{A}_{9}$ & $30,87^{\mathrm{e}}$ & $8,74^{\mathrm{e}}$ & $6,35^{\mathrm{b}}$ & $81,42^{\mathrm{c}}$ \\
$\mathrm{A} 10$ & $8,95 \mathrm{~b}$ & $3,51^{\mathrm{a}}$ & $73,65^{\text {de }}$ & $47,67^{\mathrm{a}}$ \\
\hline
\end{tabular}

Keterangan:

notasi yang berbeda menunjukkan perbedaan yang nyata antar perlakuan $(\mathrm{p}<0.05)$

\subsection{Uji Tensile Strength}

Hasil analisis sidik ragam didapatkan bahwa pengaruh perlakuan kappa caragenan, iota caragenan dan chitosan dalam perbandingan memberikan pengaruh berbeda nyata pada taraf 1 persen $(\mathrm{p}<0,01)$ terhadap kuat tarik (tensile strength) edible film. Pengaruh kappa caragenan, iota caragenan dan chitosan dalam berbagai perbandingan yang berbeda terhadap tensile strength edible film dapat dilihat pada Gambar 4.

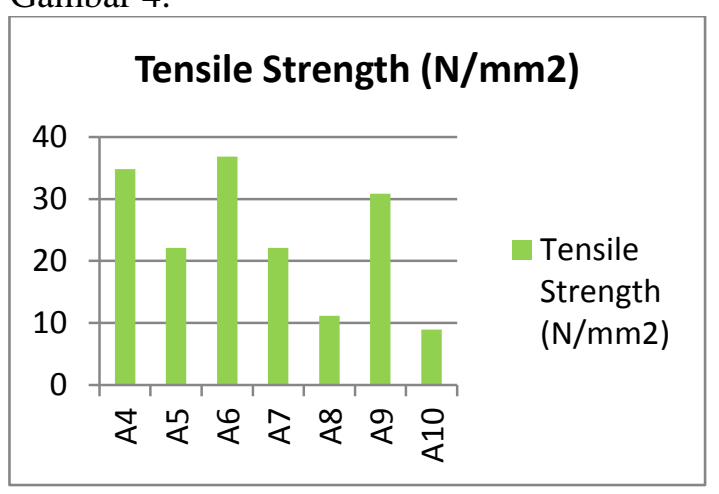

Gambar 4. Grafik hubungan perbandingan konsentrasi kappa iota caragenan dan kitosan terhadap tensile strength edible film

Pada uji tensile strength didapatkan nilai tertinggi adalah perlakuan $\mathrm{A}_{6}$ dengan perbandingan bahan kappa caragenan : iota caragenan :Chitosan (3:0:1) yaitu sebesar 36,83 dan berbeda sangat nyata dengan perlakuan yang lain. Edible film yang menggunakan bahan kappa caragenan dan chitosan tanpa dicampur dengan bahan iota caragenan mempunyai nilai tensile strenght tertinggi namun apabila dilihat secara fisik, edible film yang dihasilkan bersifat lebih kaku dan keras. Nilai kuat tarik berbanding lurus dengan ketebalan film. Semakin tebal edible film maka kuat tariknya semakin tinggi karena ketebalan berhubungan dengan meningkatnya berat molekul [13]. Diperkuat oleh [2] bahwa kappa carrageenan karena mempunyai kadar sulfat yang bermuatan negative lebih rendah sehingga dapat menghasilkan sifat film yang lebih kuat.

\subsection{Perpanjangan (elongasi)}

Hasil analisis sidik ragam didapatkan bahwa pengaruh perlakuan kappa caragenan, iota caragenan dan chitosan dalam perbandingan memberikan pengaruh berbeda nyata pada taraf 1 persen $(\mathrm{p}<0,01)$ terhadap perpanjangan (elongasi) edible film. Pengaruh kappa caragenan, iota caragenan dan chitosan dalam berbagai perbandingan yang berbeda terhadap 
elongasi edible film dapat dilihat pada Gambar 5

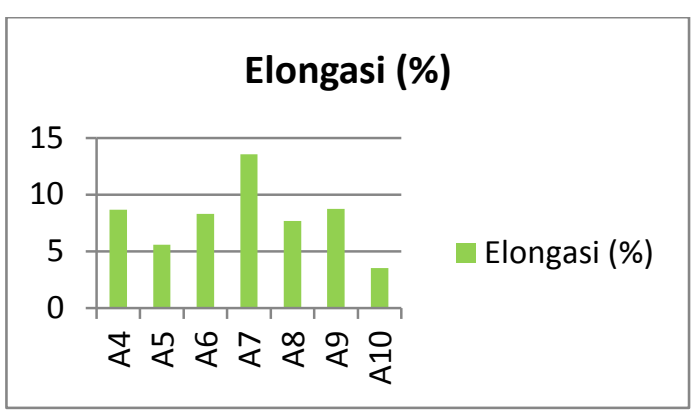

Gambar 5. Grafik hubungan perbandingan konsentrasi kappa iota caragenan dan chitosan terhadap perpanjangan edible film

Pada uji perpanjangan didapatkan nilai terbaik adalah perlakuan $\mathrm{A}_{7}$ dengan campuran bahan kappa caragenan :iota caragenan : Chitosan dalam perbandingan (3:1:0) yaitu sebesar $13,55 \%$. Nilai perpanjangan atau elongasi terendah didapatkan pada perlakuan $\mathrm{A}_{10}$ dengan perbandingan bahan kappa caragenan:iota caragenan:Chitosan (1:1:1) yaitu sebesar $3,51 \%$. Pemanjangan edible film merupakan indikasi dari kemampuan film untuk memanjang atau meregang ketika diaplikasikan sebagai pelapis atau pembungkus produk pangan. Elongasi atau pemanjangan merupakan persentase perubahan panjang edible film pada saat edible film ditarik sampai putus [14] Kappa caragenan dan chitosan dapat membentuk lapisan film yang kuat [2] sedangkan gel iota carrageenan bersifat tidak sineresis, lembut dan elastic [7].

\subsection{Transmisi Uap Air}

Hasil analisis sidik ragam didapatkan bahwa pengaruh perlakuan kappa caragenan, iota caragenan dan chitosan dalam perbandingan memberikan pengaruh berbeda nyata pada taraf 1 persen $(\mathrm{p}<0,01)$ terhadap transmisi uap air edible film. Pengaruh kappa caragenan, iota caragenan dan chitosan dalam berbagai perbandingan yang berbeda terhadap transmisi aup air edible film dapat dilihat pada Gambar 6.

\section{transmisi uap air (g/m2.jam)}

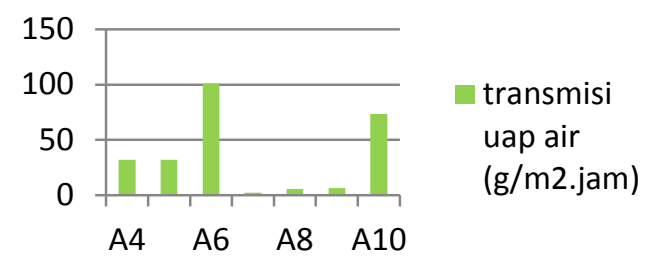

Gambar 6. Grafik hubungan perbandingan konsentrasi kappa iota caragenan dan chitosan terhadap transmisi uap air edible film

Pada uji transmisi uap air didapatkan nilai tertinggi pada perlakuan $\mathrm{A}_{6}$ dengan menggunakan bahan edible film kappa caragenan, iota caragenan, chitosan dalam perbandingan (3:0:1) dengan rata-rata nilai transmisi uap air sebesar $101,09 \mathrm{~g} / \mathrm{m}^{2}$.jam dan sangat berbeda nyata dengan perlakuan lainnya akan tetapi tidak berbeda nyata dengan $\mathrm{A}_{10}$. Perlakuan $\mathrm{A}_{6}$ tidak berbeda nyata dengan nilai transmisi uap air tertinggi yaitu perlakuan $\mathrm{A}_{10}$ dengan bahan kappa caragenan, iota caragenan dan chitosan dalam perbandingan (1:1:1). Pada Grafik 4 dapat disimpulkan bahwa perbandingan kappa iota dan kitosan dengan konsentrasi yang berbeda dapat berpengaruh terhadap nilai transmisi uap air edible film campuran kappa caragenan, iota caragenan dan chitosan.

Menurut [15] laju transmisi uap air didefinisikan sebagai laju aliran uap air (Water Vapor Permeability /WVP) melalui suatu unit area pada waktu tertentu dan pada kondisi terentu. Pengukuran nilai laju transmisi uap air suatu bahan merupakan salah satu factor yang penting dalam menentukan permeabilitas pada bahan kemasan edible film terhadap air. Sedangkan menurut [5] penentuan laju transmisi uap air (WVP) pada edible film sangat bergantung kepada kondisi pengukuran seperti suhu dan gradient tekanan uap air. [2] menambahkan bahwa carrageenan termasuk kedalam kelompok polisakarida yang anionik linier yang mengandung unit sugar, maka adanya kelompok anionik akan meningkatkan polaritas dan kelarutan air dari gum polimer tersebut. 


\subsection{Ketebalan}

Hasil analisis sidik ragam didapatkan bahwa pengaruh perlakuan kappa caragenan, iota caragenan dan chitosan dalam perbandingan memberikan pengaruh berbeda sangat nyata $(\mathrm{p}<0,01)$ terhadap ketebalan edible film. Pengaruh kappa caragenan, iota caragenan dan chitosan dalam berbagai perbandingan yang berbeda terhadap ketebalan edible film dapat dilihat pada Gambar 7.

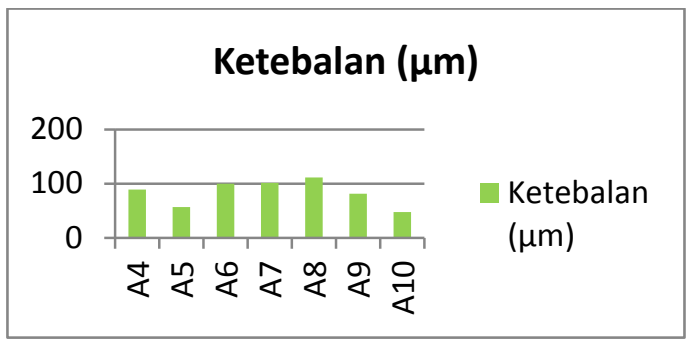

Gambar 7. Grafik hubungan perbandingan konsentrasi kappa iota caragenan dan kitosan terhadap ketebalan edible film

Pada uji ketebalan didapatkan nilai tertinggi adalah perlakuan $\mathrm{A}_{8}$ dengan menggunakan bahan kappa caragenan,iota caragenan dan chitosan dalam perbandingan (2:2:0) dengan nilai rata-rata ketebalan sebesar 111,31 $\mu \mathrm{m}$ diikuti dengan perlakuan A7, A6, A4 dan A9. Sedangkan nlai ketebalan terendah didapatkan pada perlakuan $\mathrm{A}_{10}$ dengan menggunakan bahan kappa caragenan, iota caragenan dan chitosan dalam perbandingan $1: 1: 1$, dengan nilai rata-rata ketebalan sebesar 47,67 $\mu \mathrm{m}$.Sehingga dari data tersebut dapat disimpulkan bahwa perbandingan bahan kappa caragenan dan chitosan berbanding terbalik. Semakin tinggi perbandingan kappa caragenan dan iota caragenan atau sama dan semakin rendah perbandingan chitosan atau sama, maka nilai ketebalan yang dihasilkan semakin tebal. kappa caragenan, iota caragenan dan chitosan dalam perbandingan yang sama menghasilkan nilai ketebalan yang semakin tipis dengan nilai rata-rata semakin kecil. Ketebalan edible film bukan parameter utama pada karakteristik edible film, karena ketebalan edible film dipengaruhi luas cetakan yang digunakan, volume larutan, banyaknya total padatan dan larutan. Ketebalan akan berpengaruh terhadap permeabilitas, semakin tinggi ketebalan edible film tersebut maka akan semakin kecil nilai permeabilitas dan akan melindungi produk yang dikemas dengan lebih baik [15]. Ditambahkan oleh [2] bahwa adanya muatan negative pada carrageenan dapat membentuk lapisan film yang lebih tebal dibandingkan dengan alginate dan CMC pada kelompok polimer anionic.

\section{Kesimpulan Dan SARAN}

Dari hasil penelitian dapat disimpulkan bahwa penggunaan bahan kappa caragenan, iota caragenan dan chitosan memberikan pengaruh sangat nyata terhadap kualitas edible film seperti transmisi uap air, elongasi, uji kuat tarik atau tensile strength dan ketebalan. Penggunaan bahan kappa caragenan sangat berpengaruh terhadap kualitas edible film dengan memberikan rata-rata nilai tertinggi pada uji tensile strength dan transmisi uap air.

Saran penelitian adalah penggunaan bahan kappa caragenan yang berasal dari Eucheuma cottonii dalam pembuatan edible film dapat memberikan hasil lebih baik dilihat dari kualitas fisik.

\section{UCAPAN TERIMA KASIH}

Ucapan terima kasih ditujukan kepada Fakultas Perikanan Dan Ilmu Kelautan Universitas Brawijaya Malang yang telah memberikan dukungan pendanaan bagi terlaksananya penelitian ini.

\section{REFERENSI}

[1] Krochta, J.M., Baldwin E.A, NisperosCarriedo. 1994. Edible coatings and Films to improve Food Quality. Technomic Pub.Co., Inc: Lancaster

[2] Nieto,M.B. 2009. Structure And Function Of Polysaccharide Gum Based Edible Film and Coatings in Edible Film And Coating For Food Applications Book. Springer Dordrecht Heidelberg London New York, p: 57-112. 2009 
[3] Risbud, M, Hardikar A, Bhonde R. 2000. Growth Modulation on fibroblast by Chitosan-polyvinyl pyrrolidone hydrogel : implication for wound management. J.Biosci 25(1):147-159

[4] Juang RS, Shao HJ. 2002. A Simplified $\mathrm{m}$ model for sorption of heavy metal ions from aqueous solutions of chitosan. Water Res 36(12):2999-3008

[5] Embuscado, M. E. dan K. C. Huber. 2009. Edible Films and Coatings for Food Applications. Springer. New York

[6] Setijawati, D. , S. Wijana, Aulaniam dan t. Santosa. 2011. Viabifítas dan Struktur Mikrokapsut Lactobacillus acidophilus Dengan Bahan Penyalut Caragenan Semi Murni Jenis Eucheuma cottonii. Jurnal Teknologi Pangan. 2(1): 50-67

[7] Philip, G.O., William, P.A. 2002. Handbook Of Hydrocolloids. CRC Press. Boca Raton Boston New York Washington, DC. Woodhead Publishing Limited, Cambridge England.

[8] Ramadhan, L.O.A., Radiman C.L, Wahyuningrum D, Suendo, V., Ahmad, L.O, Valiyaveetiil, S. 2010. Deasetilasi Kitin secara bertahap dan pengaruhnya terhadap Derajad Deasetilasi serta Massa molekul Kitosan. Jurnal Kimia Indonesia, 5 (1):17-21

[9] Santacruz ,S., Rivadeneira,C And Castro,M. 2015. Edible Film Based On Starch And Chitosan. Effect Of starch Source And Concentration, Plastiziser, Surfactan's Hydrophobic Tail And Mechanical Treatment. Journal Food Hydrocolloids.

[10] Huri, D, dan F. C. Nisa, 2014. Pengaruh Konsentrasi Gliserol dan Ekstrak Ampas Kulit Apel Terhadap Karakteristik Fisik dan Kimia Edible
Film. Jurnal Pangan dan Agroindustri. 2(4): 29-40

[11] Ramaniar, R.1996. Pengenalan jenisjenis Rumput laut Indonesia. Puslitbang Oceanografi LIPI. Jakarta

[12] Kurniasih, M., Dwi, K. 2011. Sintesis dan Karakterisasi Fisika-Kimia Kitosan (Synthesis And Physicochemical Characterization Of Chitosan). Jurnal Inovasi, 5(1):42-48

[13] Alsuhendra, R dan A. I. Santoso. 2012. Pengaruh Penggunaan Edible Coating Terhadap Susut Bobot, pH, dan Karakteristik Organoleptik Buah Potong pada Penyajian Hidangan Dessert. Universitas Negeri Jakarta. Jakarta..

[14] Murni, S.W., harso. P., desi. W., Novita. S. 2013. Pembuatan Edible Film Dari Tepung Jagung (Zea mays L) dan Kitosan. Prosiding Seminar Nasional Teknik Kimia Kejuangan, 1(1):1-9

[15] Tamaela P. dan S. Lewerissa. 2007. Karakteristik Edible Film Dari Caragenan. Jumal Ichthyos. 7(1): 2730 